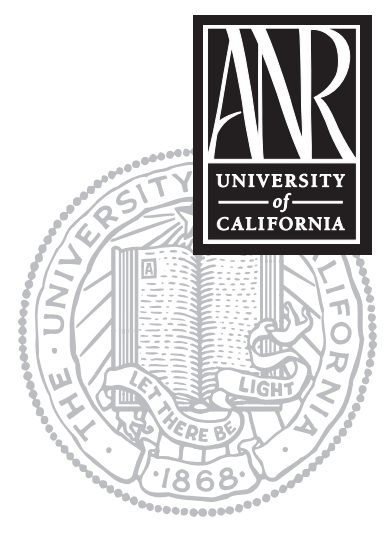

UNIVERSITY OF CALIFORNIA

Division of Agriculture and Natural Resources http://anrcatalog.ucdavis.edu

\title{
NUTRITION AND HEALTH INFO SHEET Calcium and Osteoporosis
}

ERIN DIGITALE, Department of Nutrition, University of California, Davis; CRISTY HATHAWAY, Research Assistant, Department of Nutrition, University of California, Davis; KARRIE HENEMAN, Assistant Project Scientist, Department of Nutrition, University of California, Davis; SHERI ZIDENBERG-CHERR, UC Cooperative Extension Nutrition Science Specialist, Department of Nutrition, University of California, Davis

\section{What is osteoporosis?}

Osteoporosis is a decrease in bone density and strength, resulting in increased susceptibility to bone fractures. Osteoporosis is a debilitating disease most commonly found in postmenopausal women; however, men are also at risk for this disease. In the United States, 8 million women and 2 million men have osteoporosis. ${ }^{1}$ Osteoporosis cannot be cured; it can only be prevented or its progression delayed. Mean bone density essentially remains the same between the ages of 30 and the onset of menopause. Afterward, women lose 2 to 5 percent of bone mass each year until approximately 5 years after menopause, at which time bone loss becomes more gradual. ${ }^{2}$

\section{What are the risk factors for osteoporosis?}

While genetics plays an important role in the development of osteoporosis, there are other factors that affect bone density and can therefore influence the onset of the disease.

\section{What is the relationship between calcium and osteoporosis?}

An adequate intake of calcium is essential to maximize and maintain bone density. A calcium-poor diet is a primary risk factor for osteoporosis. Calcium is lost from the bones due to menopause and aging. Many women are not obtaining the calcium levels recommended by the Dietary Reference Intakes (DRIs) in their diets. ${ }^{3}$

\section{What other nutrients are important?}

Along with calcium, it is important to consume enough vitamin D (which stimulates intestinal absorption of calcium) throughout life. While one can attain enough vitamin D from synthesis in the skin when exposed to the sun, less vitamin D is made in the skin with aging, and those who are bound to the home or hospital will have little exposure to the sun. ${ }^{4}$ For this reason, it is recommended that people at the age of 50 and older consume 800 to 1,000 International Units of vitamin D daily. ${ }^{5}$ Researchers have also noted a correlation between low protein intake and decreased bone mass, making protein another nutrient essential to bone health. ${ }^{6}$ Furthermore, diets high in fiber can interfere with calcium absorption; however, since most people do not get enough fiber in their diets, this should not be a reason to reduce fiber intake. Magnesium also plays a role in bone remodeling and older adults should be sure to consume recommended levels of magnesium from the diet as magnesium absorption decreases and renal excretion increases in this population. ${ }^{7}$

\section{What is the effect of exercise?}

Exercise is very important for bone health. A regular routine of weight-bearing exercise such as walking, jogging, or aerobics is very important to maintain bone strength. Those who need to remain immobile because of illness should consult their physician about strategies to maintain bone density. Immobility can result in the loss of a substantial amount of skeletal minerals, particularly during the first 6 months. 


\section{What is the effect of smoking?}

Smokers are more susceptible to bone loss. ${ }^{8}$ Smoking lowers the production of estrogen, causes estrogen to be metabolized more quickly, reduces calcium absorption, and is associated with early menopause. ${ }^{9}$

\section{What is the effect of caffeine?}

Consumption of caffeine is a known modifiable risk factor for osteoporosis. Research suggests that daily consumption of 2 to 5 cups of caffeinated beverages increases calcium excretion through urine. ${ }^{10}$

\section{What is the effect of alcohol?}

High intakes of alcohol increase the amount of calcium lost in the urine. The calcium lost in urine is associated with a reduction in bone mass and can increase susceptibility to the development of osteoporosis. ${ }^{10}$

\section{How can one reduce the risk or delay the progression of osteoporosis?}

\section{Consume an optimal amount of calcium}

The Dietary Reference Intakes for calcium (table 1) were determined by considering the latest research in osteoporosis prevention. These recommendations are set at the levels believed to provide maximum benefit in terms of optimizing bone density across the lifespan. Although it is important to consume enough calcium to meet these recommendations, it can be damaging to consume too much calcium. Calcium intakes above tolerable upper intake levels (ULs), shown in table 1, may be associated with serious side effects. The ULs are not an intake goal; rather, the amount shown is best for maintaining bone health.

Table 1. Current recommendations for calcium intake for various age groups

\begin{tabular}{|c|c|c|c|}
\hline $\begin{array}{l}\text { Age group and } \\
\text { pregnant or } \\
\text { lactating women }\end{array}$ & $\begin{array}{l}\text { USDA MyPyramid } \\
\text { recommended servings of milk } \\
\text { group foods per day* (cups) }\end{array}$ & $\begin{array}{l}\text { Current calcium intake } \\
\text { recommendation per day } \\
(\text { Adequate Intake })^{+}(\mathrm{mg})\end{array}$ & $\begin{array}{l}\text { Tolerable upper } \\
\text { intake level (UL) } \\
\text { per day } \text { dmg }^{\prime}\end{array}$ \\
\hline $\begin{array}{l}\text { Infants } \\
\text { birth to } 6 \text { mo } \\
7-12 \text { mo }\end{array}$ & $\begin{array}{l}\text { No recommendation } \\
\text { No recommendation }\end{array}$ & $\begin{array}{l}210 \\
270\end{array}$ & $\begin{array}{l}\text { not established } \\
\text { not established }\end{array}$ \\
\hline $\begin{array}{l}\text { Children } \\
1-3 \mathrm{yr} \\
4-8 \mathrm{yr}\end{array}$ & $\begin{array}{c}2 \text { (for children } 2 \text { and older) } \\
2\end{array}$ & $\begin{array}{l}500 \\
800\end{array}$ & $\begin{array}{l}2,500 \\
2,500\end{array}$ \\
\hline $\begin{array}{l}\text { Adolescents } \\
9-13 \mathrm{yr} \\
14-18 \mathrm{yr}\end{array}$ & $\begin{array}{l}3 \\
3\end{array}$ & $\begin{array}{l}1,300 \\
1,300\end{array}$ & $\begin{array}{l}2,500 \\
2,500\end{array}$ \\
\hline $\begin{array}{l}\text { Adults } \\
19-30 \mathrm{yr} \\
31-50 \mathrm{yr} \\
51-70 \mathrm{yr} \\
>70\end{array}$ & $\begin{array}{l}3 \\
3 \\
3\end{array}$ & $\begin{array}{l}1,000 \\
1,000 \\
1,200 \\
1,200\end{array}$ & $\begin{array}{l}2,500 \\
2,500 \\
2,500 \\
2,500\end{array}$ \\
\hline $\begin{array}{l}\text { Pregnant women } \\
\leq 18 \mathrm{yr} \\
19-50 \mathrm{yr}\end{array}$ & $\begin{array}{l}3 \\
3\end{array}$ & $\begin{array}{l}1,300 \\
1,000\end{array}$ & $\begin{array}{l}2,500 \\
2,500\end{array}$ \\
\hline $\begin{array}{l}\text { Lactating women } \\
\leq 18 \mathrm{yr} \\
19-50 \mathrm{yr}\end{array}$ & $\begin{array}{l}3 \\
3\end{array}$ & $\begin{array}{l}1,300 \\
1,000\end{array}$ & $\begin{array}{l}2,500 \\
2,500\end{array}$ \\
\hline
\end{tabular}

Source: Standing Committee on the Scientific Evaluation of Dietary Reference Intakes, Food and Nutrition Board, Institute of Medicine. 1997. Dietary reference intakes for calcium, phosphorus, magnesium, vitamin D, and fluoride. Washington, DC: National Academy Press.

Notes:

${ }^{*}$ MyPyramid.gov Web site, www.mypyramid.gov. †Standing Committee 1997, p. 15.

łlbid., p. 20. 


\section{What are good sources of calcium?}

Dairy products (milk, cheese, yogurt, etc.) are the most concentrated food sources of calcium (e.g. one cup of milk contains approximately $271 \mathrm{mg}$ of calcium). (See the metric conversion table at the end of this publication.) As shown in table 2, tofu is the most concentrated source of nondairy calcium. Even individuals who are lactose intolerant are usually able to eat small amounts of dairy products such as yogurt, cheese, and lactase-treated milk, especially when eaten as part of a meal. Those who avoid dairy products due to allergies may select nondairy foods that contain calcium, such as beans, tofu (if processed with calcium sulfate), broccoli, kale, and canned fish with bones. However, it is difficult to absorb the same amount of calcium from these nondairy alternatives as from dairy products because the overall calcium concentrations and bioavailabilities are lower. Calcium-rich foods and calcium-fortified foods are the preferred choices for obtaining calcium because additional nutrients (e.g. vitamin D in milk) can contribute to bone development and the prevention of osteoporosis. Check food labels to find out the percentage of calcium in processed foods. Every 10 percent of calcium listed on the label is equivalent to approximately $100 \mathrm{mg}$ of calcium. For those who are unable to attain sufficient calcium through their diet, supplements such as calcium citrate or calcium carbonate are recommended. ${ }^{11}$

\section{What are some food sources rich in calcium?}

Table 2. Calcium-rich food sources ${ }^{12}$

\begin{tabular}{|l|c|c|c|}
\hline Dairy foods & Serving size & Calcium (mg) & Calories \\
\hline milk (2 percent milk fat) & $8 \mathrm{oz}$ & 271 & 122 \\
\hline cottage cheese (2 percent milk fat) & $1 \mathrm{cup}$ & 156 & 203 \\
\hline mozzarella cheese (part skim, low moisture) & $1 \mathrm{oz}$ & 222 & 72 \\
\hline cheddar cheese (natural, not processed) & $1.5 \mathrm{oz}$ & 303 & 170 \\
\hline cream cheese (regular, plain) & $1 \mathrm{oz}$ & 23 & 127 \\
\hline yogurt (plain, skim milk) & $8 \mathrm{oz}$ & 452 & 183 \\
\hline Nondairy foods & & & 177 \\
\hline tofu (firm, only if processed with calcium sulfate) & $1 / 2 \mathrm{cup}$ & 861 & 118 \\
\hline sardines (with bones, in oil, drained) & $3 \mathrm{oz}$ & 324 & 137 \\
\hline salmon (pink, with bones, in water, drained) & $3 \mathrm{oz}$ & 181 & 19 \\
\hline orange juice (calcium fortified) & $8 \mathrm{oz}$ & 253 & 36 \\
\hline broccoli (fresh, steamed) & $1 \mathrm{cup}$ & 88 & 172 \\
\hline kale (scotch, fresh, chopped, steamed) & $1 \mathrm{cup}$ & & \\
\hline
\end{tabular}

The National Osteoporosis Foundation recommends taking the following steps to reduce risk of osteoporosis: ${ }^{13}$

- Consume adequate amounts of calcium and vitamin D.

- Participate in weight-bearing and muscle-strengthening exercises such as walking, jogging, weight training, or aerobics.

- Avoid smoking and excessive drinking.

During menopause, it is important for a woman to consult her physician to determine the most appropriate test of bone density, and to assess whether or not hormone replacement therapy (HRT) or estrogen replacement therapy (ERT) is needed. Replacement therapies are an effective preventative tool early in menopause, when calcium loss is greatest. Although HRT and ERT help reduce osteoporosis risk, they are not advised for all women because of their links to breast cancer and cardiovascular disease (and their other effects if used long term). Therefore, these options should be discussed individually with one's physician. 


\section{Where can more information be found?}

If an individual has personal concerns about osteoporosis, they should discuss them with a physician. General information on osteoporosis prevention, treatment, and patient advocacy is available at the following Web sites:

National Osteoporosis Foundation, www.nof.org

Osteoporosis Society of Canada, www.osteoporosis.ca

\section{REFERENCES}

1. National Osteoporosis Foundation. 2002. America's bone health: The state of osteoporosis and low bone mass in our nation. Washington, DC: National Osteoporosis Foundation.

2. Standing Committee on the Scientific Evaluation of Dietary Reference Intakes, Food and Nutrition Board, Institute of Medicine. 1997. Dietary reference intakes for calcium, phosphorus, magnesium, vitamin D, and fluoride. Washington, DC: National Academy Press. 71.

3. Ibid., p. 81.

4. Ibid., p. 255, 273-274.

5. Dawson-Hughes, B., R. P. Heany, M. Holick, P. Lips, P. Muenier, and R. Vieth. 2005. Estimates of optimal vitamin D status. Osteo Intl 16:713-716.

6. Bonjour, J. P. 2005. Dietary protein: An essential nutrient for bone health. J Am Coll Nutr 24 (90006): 526S-536S.

7. Office of Dietary Supplements. 2005. Magnesium. NIH Office of Dietary Supplements Web site, http://ods.od.nih.gov/factsheets/magnesium.asp.

8. Wong, P. K., J. J. Christie, and J. D. Wark. 2007. The effects of smoking on bone health. Clin Sci (Lond) 113(5): 233-241.

9. Standing Committee on the Scientific Evaluation of Dietary Reference Intakes, Food and Nutrition Board, Institute of Medicine. 1999. Dietary reference intakes for calcium, phosphorus, magnesium, vitamin $\mathrm{D}$, and fluoride. Washington, DC: National Academy Press. 87-88.

10. Kamel, H. K. 2006. Postmenopausal osteoporosis: Etiology, current diagnostic strategies, and nonprescription interventions. J Manag Care Pharm 12(6 Suppl A): S4-9, S26-28.

11. Standing Committee on the Scientific Evaluation of Dietary Reference Intakes, Food and Nutrition Board, Institute of Medicine. 1997. Dietary reference intakes for calcium, phosphorus, magnesium, vitamin D, and fluoride. Washington, DC: National Academy Press. 74, 81-82.

12. USDA, Agricultural Research Service, USDA Nutrient Data Laboratory. 2006. USDA National Nutrient Database for Standard Reference, Release 19. USDA Nutrient Data Laboratory Web site, http://www.nal.usda.gov/fnic/foodcomp/ search/.

13. National Osteoporosis Foundation. 2007. Osteoporosis: An overview of prevention, diagnosis, and treatment. NOF Web site, www.nof.org. 
METRIC CONVERSIONS

\begin{tabular}{|l|c|c|l|}
\hline English & $\begin{array}{c}\text { Conversion factor for } \\
\text { English to metric }\end{array}$ & $\begin{array}{c}\text { Conversion factor for } \\
\text { metric to English }\end{array}$ & Metric \\
\hline grain & 64.80 & 0.015 & milligram (mg) \\
\hline fluid ounce (fl oz) & 29.57 & 0.034 & milliliter (ml) \\
\hline fluid ounce (fl oz) & 2.96 & 0.0034 & deciliter (dl) \\
\hline ounce (oz) & 28.35 & 0.035 & gram (g) \\
\hline cup & 236.60 & 0.004 & milliliter (ml) \\
\hline
\end{tabular}

\section{FOR FURTHER INFORMATION}

To order or obtain ANR publications and other products, visit the ANR Communication Services online catalog at http://anrcatalog.ucdavis.edu. You can also place orders by mail, phone, or FAX, or request a printed catalog of our products from

University of California

Agriculture and Natural Resources

Communication Services

6701 San Pablo Avenue, 2nd Floor

Oakland, California 94608-1239

Telephone: (800) 994-8849 or (510) 642-2431

FAX: (510) 643-5470

E-mail inquiries: danrcs@ucdavis.edu

An electronic version of this publication is available on the ANR Communication Services Web site at http://anrcatalog.ucdavis.edu.

This publication has been anonymously peer reviewed for technical accuracy by University of California scientists and other qualified professionals. This review process was managed by the ANR Associate Editor for Food and Nutrition.

\section{Publication 8138}

ISBN-13: 978-1-60107-495-9

(C) 2008 The Regents of the University of California

Division of Agriculture and Natural Resources

All rights reserved.

No part of this publication may be reproduced, stored in a retrieval system, or transmitted, in any form or by any means, electronic, mechanical, photocopying, recording, or otherwise, without the written permission of the publisher and the authors.

The University of California prohibits discrimination or harassment of any person on the basis of race, color, national origin, religion, sex, gender identity, pregnancy (including childbirth, and medical conditions related to pregnancy or childbirth), physical or mental disability, medical condition (cancer-related or genetic characteristics), ancestry, marital status, age, sexual orientation, citizenship, or status as a covered veteran (covered veterans are special disabled veterans, recently separated veterans, Vietnam era veterans, or any other veterans who served on active duty during a war or in a campaign or expedition for which a campaign badge has been authorized) in any of its programs or activities. University policy is intended to be consistent with the provisions of applicable State and Federal laws.

Inquiries regarding the University's nondiscrimination policies may be directed to the Affirmative Action/Staff Personnel Services Director, University of California, Agriculture and Natural Resources, 1111 Franklin Street, $6^{\text {th }}$ Floor, Oakland, CA 94607-5201, (510) 987-0096. For information about ordering this publication, telephone 1-800-994-8849.

pr-1/08-LR/CM 